\title{
PHYSICO-CHEMICAL ANALYSIS OF DRINKING WATER OF ZILLA \\ PARISHAD SCHOOLS IN DESAIGANJ(WADSA) TALUKA, DIST.GADCHIROLI, (M.S.), INDIA.
}

\author{
A. B. Kanojiya ${ }^{1}$, S. B. Rewatkar ${ }^{1}$, S. K. Doifode ${ }^{2}$, \\ ${ }^{1}$ Mohasinbhai Zaweri College, Desaiganj(Wadsa) Dist. Gadchiroli. \\ ${ }^{2}$ Govt. Engineering College, Amravati.
}

\begin{abstract}
"Water is life" according to this slogan, water is second to oxygen as being essential for life. People can survive days, weeks or even longer without food, but only about four days without water. Thus it is essential to get pure water for drinking purpose to the mankind. So it is very necessary to assess the physico-chemical parameters of drinking water. In present study drinking water samples are collected from all fifteen Zilla Parishad Schools in Desaiganj taluka which have been assessed. The objective of study is to assess the quality of drinking water samples from Zilla Parishad primary schools, in last week of October 2013. These samples are analysed for physico-chemical parameters like temperature, $\mathrm{pH}$, electrical conductivity (EC), total dissolved solids (TDS), dissolved oxygen (DO), chemical oxygen demand (COD), total alkalinity $(\mathrm{TA})$, total hardness $(\mathrm{TH})$, chloride $\left(\mathrm{Cl}^{-}\right)$, fluoride $\left(\mathrm{F}^{-}\right)$, sulphate $\left(\mathrm{SO}_{4^{-}}\right)^{-}$, phosphate $\left(\mathrm{PO}_{4}^{3-}\right)$ and nitrate $\left(\mathrm{NO}_{3}{ }^{-}\right)$are determined. The results are compared with standards prescribed by WHO. On comparing, it is found that maximum water samples are potable for children.
\end{abstract}

Key words : Zilla Parishad Primary Schools, Physico-Chemical parameters, pollution study, drinking water, Desaiganj (Wadsa) taluka.

\section{Introduction}

"Water is universal solvent." 1 Water is our life line that bathes us, feeds us. This has always been perceived as a gift from god as it rained from the heaven. Actually $1 \%$ of water on earth is usable to us. About $97 \%$ is salty sea water, $2 \%$ is in frozen glaciers and polar ice caps. Thus that $1 \%$ of world's water supply is a precious commodity necessary for our survival. 
It is a matter of history that facial pollution of drinking water caused water-born diseases which wiped out entire population of the studied area ${ }^{2}$. As per World Health Organization, safe and wholesome drinking water is a basic need for human development, health and well being and it is an internationally accepted human right ${ }^{3}$. Water sources were polluted by domestic wastages in rural areas whereas industrial wastages discharged into natural water sources in urban areas 4,5 .

Water is polluted due to various phenomenon. The rapid growing population and improved living standards, the pressure on the present water resources is increasing day by day. ${ }^{6}$

The present work is an attempt to measure the water quality of fifteen Zilla Parishad Schools of various villages in Desaiganj (Wadsa) taluka, Dist. Gadchiroli, M.S. ( India)

\section{Material and Method}

i) Sampling \& Collection of water samples : In present investigation fifteen water samples from fifteen different Zilla Parishad Primary Schools of various villages in Desaiganj taluka, Dist. Gadchiroli, are collected in polythene bottles which were cleaned with acid water, followed by rinsing twice with distilled water. The water samples are chemically analyzed using the standard methods ${ }^{7}$. 


\section{Table 1 : Sampling sites \& places}

\begin{tabular}{ll}
\hline Sampling & \\
sites & \\
\hline $\mathrm{S}_{1}$ & Zlace \\
$\mathrm{S}_{2}$ & Zilla Parishad Primary School, Amgaon \\
$\mathrm{S}_{3}$ & Zilla Parishad Primary School, Visora \\
$\mathrm{S}_{4}$ & Zilla Parishad Primary School, Koregaon \\
$\mathrm{S}_{5}$ & Zilla Parishad Primary School, Ekalpur \\
$\mathrm{S}_{6}$ & Zilla Parishad Primary School, Boladha \\
$\mathrm{S}_{7}$ & Zilla Parishad Primary School, Chop \\
$\mathrm{S}_{8}$ & Zilla Parishad Primary School, Kokadi \\
$\mathrm{S}_{9}$ & Zilla Parishad Primary School, Tulshi \\
$\mathrm{S}_{10}$ & Zilla Parishad Primary School, Kinhala \\
$\mathrm{S}_{11}$ & Zilla Parishad Primary School, Usegaon \\
$\mathrm{S}_{12}$ & Zilla Parishad Primary School, Fari \\
$\mathrm{S}_{13}$ & Zilla Parishad Primary School, Shivrajpur \\
$\mathrm{S}_{14}$ & Zilla Parishad Primary School, Kondhala \\
$\mathrm{S}_{15}$ & Zilla Parishad Primary School, Kurud. \\
\hline &
\end{tabular}

ii) Methodology : The temperature, $\mathrm{pH}$, conductivity and dissolved solids of the water samples are determined on the spot using a thermometer, $\mathrm{pH}$ meter, conductometer and TDS meter respectively. The physico-chemical analysis of samples of drinking water are carried out according to standard methods. 8 
Table2 : Physico-chemical analysis of drinking water of fifteen different Zilla Parishad Primary School $\left(\mathrm{S}_{1}-\mathrm{S}_{15}\right)$ in Desaiganj (Wadsa) taluka.

\begin{tabular}{|c|c|c|c|c|c|c|c|c|c|c|c|c|c|}
\hline $\begin{array}{l}\mathbf{S}_{1-} \\
\left.\mathbf{S}_{15}\right)\end{array}$ & $\begin{array}{l}\text { Temp } \\
\text { oC }\end{array}$ & pH & EC & TDS & TA & TH & DO & COD & $\mathrm{Cl}^{-}$ & F- & $\mathrm{NO}_{3}$ & $\mathrm{SO}_{4}^{-}$ & $\mathrm{PO}_{4}{ }^{3}$ \\
\hline $\mathrm{S}_{1}$ & 30.5 & 6.9 & 1557 & 781 & 226 & 538 & 4.4 & 3.2 & 247 & 0.44 & 16 & 84 & 0.59 \\
\hline $\mathrm{S}_{2}$ & 31.1 & 6.6 & 1293 & 654 & 104 & 498 & 5.4 & 1.9 & 156 & 0.32 & 37 & 66 & 0.12 \\
\hline $\mathrm{S}_{3}$ & 29.5 & 7.6 & 1353 & 686 & 186 & 514 & 6.6 & 1.8 & 135 & -- & 44 & 68 & 0.18 \\
\hline $\mathrm{S}_{4}$ & 29.8 & 6.9 & 338 & 161 & 98 & 72 & 5.8 & 2.1 & 18 & 0.35 & 06 & 20 & 0.29 \\
\hline $\mathrm{S}_{5}$ & 29.2 & 6.8 & 819 & 398 & 103 & 384 & 6.8 & 1.6 & 85 & 0.38 & 36 & 27 & 0.16 \\
\hline $\mathrm{S}_{6}$ & 29.2 & 6.4 & 952 & 464 & 128 & 354 & 6.9 & 2.4 & 107 & 0.91 & 37 & 59 & 0.29 \\
\hline $\mathrm{S}_{7}$ & 29.4 & 6.6 & 1135 & 572 & 117 & 361 & 5.6 & 2.6 & 112 & 0.6 & 38 & 72 & 0.38 \\
\hline $\mathrm{S}_{8}$ & 29.8 & 6.2 & 150 & 72 & 47 & 49 & 7.5 & 1.2 & 06 & -- & -- & 37 & -- \\
\hline $\mathrm{S}_{9}$ & 29.8 & 7.3 & 1027 & 511 & 154 & 363 & 6.8 & 1.7 & 164 & 0.4 & 10 & 48 & 0.41 \\
\hline $\mathrm{S}_{10}$ & 29.4 & 7.8 & 694 & 344 & 160 & 228 & 6.6 & 1.8 & 28 & 0.41 & -- & 30 & 0.34 \\
\hline $\mathrm{S}_{11}$ & 30 & 6.5 & 669 & 326 & 122 & 253 & 6.1 & 2.2 & 52 & -- & -- & 24 & 0.16 \\
\hline $\mathrm{S}_{12}$ & 29.7 & 7.7 & 898 & 441 & 188 & 304 & 6.8 & 2.8 & 74 & -- & 12 & 35 & 0.47 \\
\hline $\mathrm{S}_{13}$ & 30.1 & 6.5 & 585 & 285 & 132 & 202 & 7.2 & 2.5 & 11 & -- & 10 & 15 & 0.19 \\
\hline $\mathrm{S}_{14}$ & 30.4 & 6.6 & 434 & 209 & 106 & 133 & 6.4 & 1.8 & 18 & -- & -- & 20 & 0.22 \\
\hline $\mathrm{S}_{15}$ & 30.1 & 7.2 & 656 & 316 & 114 & 271 & 8.9 & 2.4 & 09 & -- & 06 & 30 & 0.23 \\
\hline Min & 29.2 & 6.2 & 150 & 72 & 47 & 49 & 4.4 & 1.2 & 06 & 0.32 & 06 & 15 & 0.12 \\
\hline Max & 31.1 & 7.8 & 1557 & 781 & 226 & 538 & 8.9 & 3.2 & 247 & 0.91 & 44 & 84 & 0.59 \\
\hline WHO & - & $\begin{array}{l}6.5 \\
- \\
8.5\end{array}$ & 1400 & 1000 & 120 & $\begin{array}{l}200 \\
- \\
600\end{array}$ & - & 10 & 250 & 1.5 & 45 & 250 & -- \\
\hline
\end{tabular}

(all parameters are in $\mathrm{mg} / 1$ except $\mathrm{pH}$ and $\mathrm{EC}, \mathrm{EC}$ is in micro-siemens,)

\section{Result \& discussion:}

It is very essential and important to test the water before it is used for drinking. Water must be tested with different Physico-Chemical parameters.

Total fifteen water samples from Zilla Parishad primary schools are analised for physico-chemical parameters like pH, EC, TDS, TA, TH, DO, $\mathrm{COD}, \mathrm{Cl}^{-}, \mathrm{F}^{-}, \mathrm{NO}_{3}{ }^{-}, \mathrm{SO}_{4}{ }^{-} \& \mathrm{PO}_{4}{ }^{3-}$. The aim of the study is to evaluate drinking water quality available in above Zilla Parishad Primary schools.

\section{Temparature}

Temperature is an important biologically significant factor, which plays an important role in the metabolic activities of the organism. In the present study, temperature ranges from 29.2 to $31.1^{\circ} \mathrm{C}$. 


\section{pH}

$\mathrm{pH}$ is most important in determining the corrosive nature of water. lower the $\mathrm{pH}$ value, higher is corrosive nature of water. $\mathrm{pH}$ was positively co-related with electrical conductance $\&$ total alkalinity. ${ }^{9}$ The $\mathrm{pH}$ value varies between 6.2 to 7.8 .

\section{EC}

Electrical conductivity (EC) is the measure of water capacity to convey electric current it signifies the amount of total dissolved salts. EC value varies from 150 to 1557 micro-siemens, which reveals that EC values for $\mathrm{S}_{1}$ sample are comparatively higher value than other, indicating the presence of high amount of dissolved inorganic substances in ionized form. ${ }^{10}$

\section{TDS}

Total dissolved solids (TDS) indicates the general nature of water quality. In present investigation TDS value varies from 72 to $781 \mathrm{mg} / 1$. It was reported that alkaline water are richer in solids than acidic water. The quantity of TDS was proportional to the degree of pollution. ${ }^{11}$

\section{DO}

Dissolve oxygen (DO) is one of the most important parameter. Its co-relation with water body gives direct \& indirect information e.g. bacterial activity, Photosynthesis, availability of nutrients, stratification etc. ${ }^{12}$ In present investigation DO values varies from 4.4 to $8.9 \mathrm{mg} / 1$.

\section{COD}

Chemical Oxygen Demand (COD) is another measure of organic material contamination in water. COD is the amount of dissolved oxygen required to cause chemical oxidation of the organic material in water. COD values varies from 1.2 to $3.2 \mathrm{mg} / 1$. 


\section{TA}

Total alkalinity (TA) of water is measure of its capacity to neutralized acids. This is due to the primarily salts of weak acids or strong bases. Bicarbonates represent the measure form of alkalinity. Bicarbonates are formed in considerable amount from the action of carbon dioxide upon basic materials in soil \& other salts of weak acids. ${ }^{13}$ The alkalinity values varies from 47 to $226 \mathrm{mg} / 1$.

\section{TH}

Total Hardness (TH) is a measure of capacity of water to precipitate the soap. Hardness of water mainly depends upon the amount of calcium or magnesium salt or both. In present study $\mathrm{TH}$ value varies from 49 to $538 \mathrm{mg} / 1$.

\section{$\mathrm{Cl}^{-}$}

Chloride is a natural substance present in all portable water as well as sewage effluents as metallic salts. The Chloride value varies from 6 to $247 \mathrm{mg} / 1$. High chloride ion concentration indicates organic pollution in water.

$\mathbf{F}^{-}$

Probable source of Fluoride in Indian water seems to be that during weathering and circulation of water in rocks \& soils, Fluorine is leached out \& dissolved in ground water. Excess intake of fluoride through drinking water causes fluorosis in human being. In present analysis Fluoride value varies from 0.32 to $0.91 \mathrm{mg} / 1$ are within the permissible limits for all samples. 
$\mathrm{PO}_{4}{ }^{3-}$

Phosphates come from fertilizers, pesticides, industries \& cleaning compounds. Natural sources includes phosphates containing rocks \& solid or liquid wastes. These are classified as orthophosphates, condensed phosphates \& originally bound phosphates. Phosphate value varies from 0.12 to $0.59 \mathrm{mg} / 1$.

\section{$\mathrm{NO}_{3}-$}

The measure source of accumulated nitrates \& nitrites in water include breakdown of organic matter through mineralization, hydrolysis, microbial action $\&$ nitrogen fixation. ${ }^{14}$ Nitrate value varies from 06 to 44 $\mathrm{mg} / 1$.

\section{$\mathrm{SO}_{4--}^{--}$}

Sulphate is one of the least toxic anions for drinking water. But it is important due to its cathartic effect in some human when present in excessive amount. Sulphate may occur due to industrial discharge, contaminant from mines, paper mills etc. The values of Sulphate varies from 15 to $84 \mathrm{mg} / 1$.

The above result reveals that $\mathrm{EC}, \mathrm{TDS}, \mathrm{TA}, \mathrm{TH}, \mathrm{Cl}^{-}$and $\mathrm{SO}_{4}^{--}$ values for $\mathrm{S}_{1}$ sample are comparatively higher value than other.

\section{Conclusion:}

The drinking water from different Zilla Parishad Primary Schools are analysed. The analysis report suggested that the water quality parameters lie within the maximum permissible limit prescribed by WHO. Incase of sample $\mathrm{S}_{1}$ most the parameters are having comparatively higher value. It is due to sewage. Hence as per this report drinking water in maximum Zilla Parishad Primary School in Desaiganj (Wadsa) taluka Dist. Gadchiroli are suitable for drinking purpose. 


\section{REFERENCES}

Subha Srivastava, M.Kumar,J.Singh,K.K. Srivastava \& G.Singh, (1999). Indian J. Environmental Protection, 19(9),641.

S.S. Yadav, Rajesh Kumar, (2010). Rasayan J.Chem., 3(3), 589-596.

WHO,Guidelines for Drinking water Quality 3rdEd, World Health Organisation, Geneva 2004.

A.K.De, (1994). 'Environmental Chemistry',3 ${ }^{\text {rd Ed,New }}$ Age International(p) Limited, Publishers, New Delhi.

J.A. Sayyad \& A.B. Bhosle, (2010). Der Chemica Sinica, 1(2), 104.

S.Patel and S.H.Quadri, (2011). Der Chemica Sinica, 2(5), 194.

American Public Health Association, (1992). 'Standard Methods of Examination of Water and Waste Water,' 18 th Ed,(Eds.Greenberg, Clesceri and Eaton), U.S.A. 2340.

APHA, 1998. Standard methods for the examination of waste water. American public Health Association, Washington D.C 874.

Gupta, D.P., Sunita and J.P. Saharan, (2009), Physiochemical Analysis of Ground Water of Selected Area of Kaithal City (Haryana) India, Researcher, 1(2), pp 1-5.

Sudhir Dahiya and Amarjeet Kaur, physico-chemical charecteristics of underground water in rural areas of Tosham subdivisions, Bhiwani district, Haryana,J.Environ.poll., 6(4),281 (1991).

Nasrullah, Rafia Naz, Hamida Bibi, Mudassar Iqbal and M.Ilyas Durrani, Journal of Agricultural and Biological Science, 2006, Vol.1,No. 3, 18.

Premlata Vikal, (2009), Multivariant analysis of drinking water quality parameters of lake Pichhola in Udaipur, India. Biological Forum, Biological Forum- An International Journal, 1(2),pp 97-102.

O.D. Ansa-Asare and K.A. Asante, West Afr.J.Appl. Ecol. 2000, 1,23.

Fadiran AO, Mamba SM (2005), Analysis of nitrates and nitries in some water and factory effluent samples from some cities in Swaziland Bull. Chem.Soc.Ethopia, 19(1):35-44. 